\title{
1. Black and Blue: Shades of Violence in West New Britain, PNG
}

\author{
Naomi McPherson
}

\section{Abstract}

In this chapter, I am concerned to take up what Galtung argues are the two problems to be dealt with in violence research: 'the use of violence and the legitimation of that use' especially 'those aspects of a culture that serve to justify and legitimize violence' (1990: 291). I begin with a brief discussion of Bariai cosmology to provide background to Bariai concepts of gender and how the enculturation process engenders men, women and children. This is followed by a consideration of violence experienced by women as women, spouses, school girls, and as members of their faith within a changing cosmology manifested most recently by a shift to fundamentalist charismatic Catholicism. My basis for this discussion assumes violence is about power differences and power inequities are a necessary and sufficient condition for violence, and my primary goal is to delineate those aspects of Bariai culture that make 'violence look, even feel right — or at least not wrong' (Galtung 1990: 291).

\section{Introduction}

The May 1986 'Seville Statement on Violence' (in Hussey 2003: 355-57) debunks essentialist, biologically reductionist explanations for human violence. In statements that begin 'It is scientifically incorrect' the authors point out that (1) humans have not inherited violent tendencies from our primate ancestors; (2) violent behaviour is not genetically inherited; (3) aggression was not selected for in human evolutionary history; (4) human neurophysiology does not compel us to violence; and, (5) violence is not instinctual in humans. While certainly capable of violence, the notion that violence is a biologically determined and evolutionarily honed human (genetic) trait needs to be vigorously critiqued and ruled out (see McCaughey 2008; also Tracy and Crawford 1992). It has been estimated that 67 per cent of gender violence in Papua New Guinea (PNG) is husbands abusing their wives and that 'men are far more likely to be the perpetrators of violence, regardless of the sex of the victim. Masculinity, thus, has a role in promoting and legitimising the use of violence; in many prevailing 
models of masculinity, violence is seen as a normal and entirely justified way of resolving conflict or expressing anger' (Eves 2006: 15). But we cannot argue that males perpetrate violence against females because they are biologically bigger and stronger, or because they are hormonally predisposed to be aggressive. To accept this is to accept the worst form of biological reductionism and gender essentialism, and leaves no options for change (except perhaps through genetic manipulation). We need to consider that violence is not a human genetic trait, that it may very well be a cultural trait, learned, practised, and integral to cultural concepts of gender. My objective in this chapter is to explore how violence is engendered and embodied in a West New Britain society.

For decades, anthropologists have documented male socialisation and cultural concepts of masculinity as an essential part of the 'rituals of manhood' in many Papua New Guinea societies (Herdt 1982; Gewertz and Errington 1991: 58-100; Tuzin 1997; Zimmer-Tamakoshi 2001). Generally, in these male initiation rites, boys are taught cultural concepts of male privilege, superiority, and dominance over women and youth. The rites themselves more often than not include some form of physical violence (e.g., thrashing, deprivations, cicatrisation, cane swallowing, abrasion with stinging nettles) inflicted by adult kinsmen on boys to eliminate female essences from their bodies in order to re-create (rebirth) those boys as strong men and members of their kin groups. During male initiation rituals, John Fitz Porter Poole reports that Bimin-Kuskusmin boys 'are negatively identified with female characteristics ... [and] are physically controlled, harangued and abused with respect to their female substance, food, and behaviour' (1982: 117). Thus, by purging them of female essences, initiation rites 'transform gentle boys into warriors capable of killing rage, stealthy murder, and bravery' (Keesing 1982: 3), men who are taught to fear 'the dangers to men which are posed by women's natures' (Hays and Hays 1982: 206). ${ }^{1}$ In this way, an aggressive, violent culture of masculinity is literally inscribed on young, male bodies and when this culture of gender is perpetuated within changing social and economic structures, we have, as Laura Zimmer-Tamakoshi puts it, 'troubled masculinities' and increased violence (Ch. 2: 58). One aspect of this chapter is to show how children in a PNG society, which does not practise any violent form of male initiation, learn to be violent in their interactions with one another and with adults and how, as boys and girls grow into men and women, violence becomes an embodied aspect of their personality and their gender identity.

\footnotetext{
1 It is interesting to note that Melanesian masculinity is seen as so connected to culture, as in learned not biological; whereas femininity is considered to be an essential feature of female 'nature'. There has been a theoretical disjuncture in discussions of gender in Melanesia which has overlooked how females learn their culturally approved femininity.
} 
Despite recent efforts to theorise a cultural concept of violence (Riches 1986; Krohn-Hansen 1994; Dinnen and Ley 2000; Stewart and Strathern 2002), what constitutes 'violence' is a contested issue. The contributors in Sinclair Dinnen and Allison Ley (2000) speak to the variety and complexity of different types of violence in contemporary Melanesian cultures. There, violence ranges from actual physical violence characteristic of spousal abuse to metaphorical rhetorical violence, for example, when a transnational company talks about 'driving a spear of development into the heart of Irian Jaya' (Banks 2000: 254). My basic premise here is that violence, like gender relations, is always about relations of power, more specifically, 'power over' in the sense of both structural violence, where violence is based on inequality - economic, political, social, religiousand cultural violence where individuals are enculturated to a system of beliefs that hold violence to be legitimate and normal. Thus, violence-whether physical, psychological, verbal, spiritual - is, broadly, acts against another who consequently suffers negatively - pain, disadvantage, fear, disempowerment. In this rendering, colonialism is a form of violence, as is state-induced structural violence, which results in disadvantage, poverty and other forms of harm for people (Galtung 1990; see also Farmer 2004, 2005). My definition of violence also includes spiritual violence (Stewart and Strathern 2002: 89) such as acts or threats of witchcraft (see Gibbs, Ch. 3), sorcery and spirit beings, as well as spiritual violence as a consequence of contemporary Christian beliefs and practices (see Hermkens 2007, 2008 and Ch. 4). Invoking gender violence typically draws the mind to concentrate on domestic violence, usually violence against women perpetrated by men who are usually the women's spouses but sometimes their fathers, brothers, or sons (e.g. see Chowning 1985; Counts 1992; Counts, Brown and Campbell 1992; Hammar 1996; Wardlow 2006). Violence also occurs outside the spousal relationship, perpetrated by women against other women, men against other men, adults against children, and even children against adults, and, as Wardlow (2006: 75) shows so effectively, even forms of negative agency, violence against oneself that usually results in self-harm (see also Counts 1993). However, violence against women by men is the most prevalent form of gendered violence today (Heise 1997: 414). In this paper I focus primarily on spousal violence, grounded in the hegemonies of patriarchal masculinity, and men's physical and emotional violence against women's overburdened bodies, their spirit, self-esteem and quality of life. Women grow up and enter marriage knowing that their words, behaviours and, indeed, their agency could ignite their husbands' anger and result in abuse. Masculine violence finds its outlet on female bodies which are hit, kicked, cut, violently bruised, battered and broken; they are made black and blue.

Taking these shades of violence as given, I want especially to consider how cultural concepts of gender and power imbalance (woman/man; adult/child; young/old) permit and legitimise violent masculine behaviour toward girls and 
women, and how these cultural concepts prevent women (and men) from seeing any alternatives to the abuse and disempowerment they live with on a day-today basis. Questions arise about how girls and women come not only to expect masculine aggression directed towards them, but also to accept that they must endure that violence; in other words, how does the structure and meaning of gender violence persist and become normalised (see Heise 1997: 424; McCaughey 2008). To help think about these issues, I am adapting Johan Galtung's concept of 'cultural violence' defined as 'those aspects of culture, the symbolic sphere of our existence - exemplified by religion and ideology, language and art, empirical science and formal science ... that can be used to justify or legitimize direct or structural violence' (1990: 291). Here I am particularly concerned to take up what Galtung argues are the two problems dealt with in violence research: 'the use of violence and the legitimation of that use' especially, 'those aspects of a culture that serve to justify and legitimize' violence (1990: 291). Clearly, rather than assume an innate or essentialist theory of masculine violence we need to explore the ideological, socio-economic and spiritual ethos that permits and perpetuates violence. Gender relations are relations of 'power over', more specifically, gender asymmetry is a structure of violence, reflected in masculine domination/feminine subordination. My primary goal is to explore those aspects of culture that make structures of 'violence look, even feel right - or at least not wrong' (Galtung 1990: 291, my emphasis).

My discussion is framed within my ethnographic work over several years with the Bariai, who live in the province of West New Britain, Papua New Guinea. The Bariai are subsistence horticulturalist and fisher folk whose ten villages are spread along the northwest coast of the province. They are sufficiently removed from the centres of urban and peri-urban development that no road finds its way to them, sea transport is sporadic, unreliable, and expensive, and there are no amenities such as power or piped water. Access to the 'bright lights' of modernity only exist in the provincial capital at Kimbe, over two hundred kilometres by sea away and most women and many men don't get there. Over the six occasions from 1981 to my visit in 2009, I have witnessed an entire generation of young people grow up, raise their families and take the place of their elders. All the elders with whom I began my research in 1981 were deceased by 2009. Other changes included a doubling of the population and almost a tripling of population in the village where I normally reside, the demise of the men's secret-sacred ritual house (lum) and the presence of a strong charismatic Catholic movement whose leaders are predominantly represented as current village leaders. While I discuss shades of violence within this ethnographic context, it needs to be clearly understood that the Bariai are no more violent than any other social group in PNG; indeed, there is far less violence in Bariai 
culture and society than in many other cultures in Papua New Guinea. ${ }^{2}$ Over the course of working with the Bariai during this time period, I have accumulated a number of examples and explanations of violent events - gendered violence in particular - that, when articulated in one breath, so to speak, may give the impression that the Bariai are a violent people. Nothing could be further from the truth. This discussion is thus situated in a historical and cultural context, and people's understanding of, and participation in, social, cultural and economic change in the globalising world they inhabit.

In terms of a world view that legitimises violence, I begin with a brief excursion into Bariai mythology to explore a primal charter for masculine violence against women. The myth not only locates masculine empowerment and feminine disempowerment in a primal past, thus normalising masculine acts and experiences of violence as a kind of ascending anachronism, but also sets a mythic precedent for a type of spiritual violence against women. I then discuss how mythic charters play out on a day-to-day level in considerations of violence experienced by women because they are female - wives, daughters, schoolgirls - and how violence is taught by adults and learned by children in the guise of creating strong persons who stand up for themselves. Finally, I explore a kind of spiritual violence experienced by women as members of their faith, especially of Catholicism as understood and practised here, that reinvests and reinforces masculine hegemonies: the authority of men, the father as head of household, and masculine sexual privilege. My overarching point is to expand our understanding of engendered violence as a non-reductive, highly complex, structurally situated cultural concept that creates, informs, and condones violent acts against others.

\section{Primal violence in Bariai mythology}

Creation myths which set precedents for gender relations are common throughout Melanesian cultures (e.g. Gewertz 1988) and, equally commonly, these myths often depict what Eric Silverman (2001: 104) calls the 'primal theft of sacra' from women by men. This Bariai origin story was immediately offered to me as an 'answer' in response to my question, why women and uninitiated youth and children of both sexes, had to 'run away' from the village in anticipation of the entrance of Tivuda, a spirit being. As Bariai understood it, ${ }^{3}$ the universe, and

\footnotetext{
2 The Bariai do not practise any physical ritual violence against children beyond ear-piercing (girls) and superincision (boys).

3 I use the past tense purposely as this and other origin narratives are heavily overlaid now by Christian origin narratives, such as Genesis. Which of these creation stories (or a syncretic version of them) were offered as a means to understanding Bariai cosmology depended on to whom I was speaking and the context of that discussion.
} 
all it contains, including humans, was created by Upuda (B: $p u$, origin; da, our). Upuda created human beings, one female and one male, carved from a single piece of wood divided into equal halves. The two humans prospered, bearing fifty children and they all lived in a primal men's house (B: lum) together with autochthonous spirit beings. And so time and events passed....

One day, women were chopping firewood from a mangrove tree called Taltalnga when a piece of wood flew off making a whirring noise. The surprised women exclaimed, 'Oh, how wonderful!' and made it sing again. Later, they took it back to the village and hid it from the men. One day the women prepared a huge feast of taro pudding. They designated one person, called Ola [B: messenger], to send the men from the village so they wouldn't see the Bullroarer [B: Tibuda]. When the women were ready to 'pull' the Bullroarer, Ola put on ceremonial finery and sent the men away. While they were gone, Bullroarer entered the village plaza to sing and eat pork and roasted taro with the women. When Bullroarer went back inside the woman's house [B: luma], Ola called the men back. And so it was for some time.

After a while, the women constructed a ceremonial food platform [B: kabokabo] and prepared a large feast for the Bullroarer. As before, Ola sent the men away, and during the exodus, an old man tripped, spilled his lime powder and broke his lime spatula. 'What's going on?' he exclaimed angrily. 'These women have us running in all directions while they stay here and do things with their Bullroarer.' The old man conspired against the women. He sent lengths of shell-money attached to pieces of women's grass skirts [a call to battle] to every men's house [B: lum]. On the prescribed day, all the men's house groups joined against the women. From the oldest grandmother to the littlest girls, they were all killed. The only females spared were infant girls who still suckled. The men captured the Bullroarer and now no woman knows how to make it sing because the memory was killed. Since that time, the Bullroarer has belonged to men and women flee its fearsome presence.

That women once interacted with powerful autochthonous spirit beings and were displaced by men who stole from the women those artifacts symbolic of that spirit being (the 'primal theft of sacra') is, as we have seen, a common theme in Melanesian creation stories. In this story, all is fine until a senior male falls and breaks the gourd holding his lime powder and spatula for preparing betel nut. The lime powder gourd and spatula are metaphors for female and male genitalia respectively and to tell a man that 'your lime powder has spilled' is to point out that his genitalia are exposed. When an old man falls, spills his lime powder and breaks his spatula (a metaphor for a detumescent penis), his anger at his emasculation knows no bounds as he seeks to avenge his masculine 
pride by punishing the women. But men do not simply take over; they violently dispossess the women by calling for a true gender war. They send messages to men in other villages who attend a battle whose sole purpose is to murder all females who had any knowledge of the origins of the Bullroarer and its emasculating relationship with men. Female infants at the breast are spared only because they have no capacity for speech, and hence, no way of knowing. These infants grew up to become wives with no memory of the origin of Bullroarer or the gender war; consequently, they were no threat to men's control of the spirit being and its autochthonous primal powers. Now, when the Bullroarer comes to the village, women are excluded on pain of death from seeing or interacting with the Bullroarer. Although all those females who might have remembered this incident were killed, the memory of the women's loss of their primal sacra and interaction with the powers of the cosmos is invoked through this mythic narrative that all women and girls have heard many times during their lives, not least when it was told to this anthropologist. To this day, the Bullroarer is a terrifying and destructive spirit being for all, and is summoned to avenge a wrong committed against a firstborn child.

Interestingly, men are not condemned for their femicide in this myth; indeed, men often exclaim at the barbarism of their ancestors, which they, as the contemporary generation have transcended. The story is a 'social charter' in the Malinowskian sense, which explains why things are the way they arewomen must not interact with spirit beings - and should they transgress, they will be killed, thus things should remain the way they are. An ascending anachronism pushes events back into the dim recesses of time thus normalising and naturalising those events which we now call upon to explain why things are the way they are, in this instance, why women run away from the Bullroarer. Ascending anachronisms become a circular logic or tautologies in explaining why things have to be the way they are, because of that normalising process (see Conkey and Williams 1991). Women's exclusion from male sacred powers is upheld until today through threat of death at the hands of that spirit being. When I asked what would happen if women ventured into the men's house and its environs when a spirit being was in residence, both men and women responded that she would be taken into the men's house, gang raped, murdered, unceremoniously buried in the men's house, and her jaw bone would be thrown into the village plaza as a lesson to all other women. No one would be permitted to grieve or bury her, and she would never be spoken of again. This legitimised cultural violence creates fear in women and they learn not to impinge on masculine spaces and activities. Should they transgress, the myth legitimates masculine violence in the form of institutionalised rape, murder, and dismemberment as punishment, a 'teaching moment' to deter other women from similar transgressions. Rather than seeing injustice, women take the men's murderous behaviour as a cautionary tale that they should not involve 
themselves with spirit beings (and male sacra) since, to do so, is to risk death and/or gang rape for their transgression. This overarching threat of rape and murder in order to keep women in their place - that is out of men's places - fits with Jane Caputi's (1989: 439) definition of rape and sexualised murder as being 'direct expression[s] of sexual politics ... ritual enactment[s] of male domination, a form of terror that functions to maintain the status quo.'

This fraught relationship between women and feminine things and spirit beings runs through a number of Bariai stories (McPherson 2008a; 1994). Myths also explain how the distribution of peoples and languages is founded on sexuality and gender violence: long ago, when fifty men's houses still existed, an Aulu spirit being seduced a married woman. Her cuckolded husband was furious and instigated a brutal war between humans and spirit beings. Terrified, people fled and resettled throughout northwest New Britain. This war resulted in severing the relationship between human beings and spirit beings who now inhabit separate domains which intersect only on ritual and ceremonial occasions. In another myth, women laugh and 'play' (a euphemism for sexual intercourse) with spirit beings who are processing sago for the women. Men spied on the women and due to their sexual jealousy, declared that henceforth men would process sago and interact with the spirit beings. But the spirit beings were so offended by the men's jealousy that they removed themselves from the human domain, leaving the hard work of processing sago to the men. Access to the power of the spirit beings and the domain of the sacred-once the privilege of females - is now the prerogative of males. Their possession of the primal sacra and these stories offer precedents and thus justifications for why this is so. The consequence for women is spiritual disempowerment reinforced by fears of masculine violence justified by mythic social charters.

While we might dismiss these stories, these rationalisations of masculine violence against women as mere myth, in reality all women fear for their persons and their lives during the presence of spirit beings. Let me offer some examples. In 1981, a young woman visitor went looking for the women's bush toilet, unintentionally walking into the place where men were preparing for a spirit being. She was grabbed, trussed like a pig, and carried back to the village where men debated for a very tense few hours about what to do (gang rape was favoured over murder). In the end, cooler heads prevailed and her father was made to pay compensation for her transgression, including a tusked pig, to the spirit being resident in the men's house. On another occasion in 1983, when we women, uninitiated youths, and children were called back to the village after the Bullroarer spirit had rampaged through, we discovered that an elderly woman had fallen asleep while peeling sweet potato and stayed behind in her house. The men held a long and stressful discussion among themselves (causing fears and tears among the women) to determine the old woman's fate; all of 
us, including the old woman herself, feared for her life. In the end, the men decided that she was old, thus on the cusp of the spirit domain herself (death), and no harm should befall her provided she pledged (and she did) not to reveal anything to the excluded group about what she may have seen or heard while the Bullroarer was manifest in the village. In another instance, in 1985, a new men's house was being constructed and the central posts (B: kadanga aranga; 'male posts') erected. Women who normally left the village due to the nearness of spirit beings were permitted to remain by senior men of that men's house. While I couldn't believe my ethnographic good fortune, the women were exceptionally uncomfortable: they stayed away from the construction site, refused to look at the work going on there, and found other paths to get to their destinations rather than walk by the site. When construction difficulties plagued the erection of the 'male house posts' (B: aranga kadanga), the men concluded that the spirit beings were angry because women had not left the village. Women's fears are thus deeply enculturated and do not go away simply because men lift a restriction that previously, if breached, would have cost women their lives. Moreover, having lifted the restriction, men still blamed women's essential femaleness for failures in the process of their construction.

\section{Violence in the name of the father: Domestic violence}

Bariai mythology relates the wresting away from women of their spiritual powers, with a simultaneous minimising of their earthly powers. In a patriarchal, maledominated society, Bariai women are not only systematically excluded from the spiritual sources of male power (access to spirit beings), but they experience everyday secular gender inequalities in myriad forms. Cultural constructions of gender define the essential 'nature' of woman/the feminine ambiguously. Negatively, women are dangerous, weak-willed, weak-minded, and their bodies are soft and leaky. Women's bodily fluids and their physical presence can negatively affect male enterprises and virility, hence the necessity to keep women away from male places and spaces. On the positive side, women have powers for creation. It is those soft, damp and creative female bodies that bring forth children who are indicative of a man's virile masculinity, exemplars of parental renown, and a source of paternal wealth through their labour and marriages. As a wife, an adult woman's productive labour supplies men with food, pigs and other forms of wealth that men publicly transact to gain socioeconomic prestige and political renown (in a system of prestige akin to what has been designated the Bigman system). 
Although the female is defined as weak minded, men fear women's knowledge and are suspicious of women's abilities to use contraceptives or abortifacients and condemn these practices. All men are considered fertile by nature and capable of fathering children; no male is thought sterile. Women, too, are considered fertile as part of their inherent nature; thus, a woman who does not become pregnant in a reasonable time after marriage (or does not conceive often enough) faces spousal violence because female sterility is not natural, but rather a consequence of her actions: she must have engaged in adultery or she has utilised contraceptives. ${ }^{4}$ Women are deemed by men to be lustful and overly jealous and not in control of their sexuality; thus men need to control it for them. When a wife invariably quarrels with her husband's other wives or mistresses, she is likely to be beaten by her husband and her father for not being stoical and accepting of her co-wives, and for disobeying her husband's demands that she accept his decision on polygyny. Women, like children, must be constantly socialised (see Eves 2006: 24), a process that is beaten onto their bodies in order that, among other things, they learn a lesson, do their work, behave properly, and show the proper degree of obedience to their fathers and husbands. Given that much adult violence is perpetrated by men on their wives and daughters, the question arises: Are men monsters? Of course they are not. From birth women and men have learned these cultural constructions of gender and sexuality, gendered role expectations, values and behavioural norms as part of their world view. All children are enculturated to be aggressive towards others; this is not seen as a 'bad' thing, but as a positively acquired trait for developing a strong personality. Small children and infants are encouraged to 'pait em, pait em' a Tok Pisin (TP) phrase meaning 'hit her' or 'hit him'. Even in infancy, the person holding the child will take the child's arm and make hitting motions towards the other person while laughing, 'hit him, hit her'. Small children, even before they learn to walk or talk, learn to hit other children (and animals), and children of all ages will hit their parents and other adults all of whom think this is 'cute', childish behaviour. During play when children disagree, feel wronged, slighted, or teased, with no encouragement at all, they will aggress the other child(ren) and fight with hands, feet, rocks, sticks or other handy objects (fishing spears, knives). Children of all ages, are struck and/or beaten by their mothers, fathers or elder siblings of either sex for disobeying, skipping school, perceived laziness, eating food they shouldn't have, and other transgressions. Children, male and female, grow up surrounded by aggression and violence and become aggressive adults and, in the case of women, 'learn' how to be the recipient of the violence of others, particularly from their husbands.

4 I have written about this in more detail in Scaletta 1986. 
Many incidents of abuse came to my attention over the years as women (but only one man) came to me for first-aid for their wounds, some of which are related below.

\section{Some scenarios of spousal violence}

Case 1. (1982) A young man arrived at my house with a long, deep gash on the back of his calf muscle. As I cleaned and dressed the wound, I asked what happened. He told me it was an accident; he had slipped off his house ladder and gashed his leg on a piece of corrugated metal roofing. After he left, the women sitting with me burst out laughing and told me that, in reality, he and his wife had quarrelled and his angry wife, tired of him accusing her of infidelity, attacked him with her bush knife.

Case 2. (1983) A young couple was having ongoing marital arguments and physical fights. The husband was often away for weeks at a time in the provincial capital and when he returned to the village they argued and each accused the other of infidelity. The wife came to me with a deep gash on her head where her husband had hit her with a heavy metal spoon. Not long after this incident, the wife attempted suicide by drinking bleach; in great pain and near death she was taken to the local clinic some fifty kilometres away. She did recover, but eventually left the marriage.

Case 3. (1983) A newly married woman from another village asked me to dress a very nasty cut on her shoulder delivered by her husband as he whipped her with his bush knife. The issue was her seeming inability to become pregnant, despite being married for several months. This marriage broke beyond repair, as eventually the woman went back to her family to escape ongoing beatings.

In these three examples, sexual jealousy plays a large role in spousal relations and abusive behaviour, as does male sexual privilege and any challenges to it. But it is not just women who are jealous. The man above lied to me to cover his shame and embarrassment that his wife had attacked him in response to his constant harangue charging her with infidelity while he was away. The women who witnessed this interaction told me that when provoked by men, women grab a stick, piece of firewood, canoe paddle as a weapon for hitting their husbands. Using a 'weapon' is culturally unacceptable for men when beating their wives; it is acceptable for women because they are perceived to be at a disadvantage in size and strength. Women don't always succeed in hitting their spouses, but when they do, the reaction is laughter from others rather than condemnation. Men's jealousy, even insecurity about their wives' feelings for them, is expressed in physical lashing out, both to defend their masculinitythey won't be cuckolded - and, presumably, with the intention of instilling in 
their wives proper spousal behaviour, such as ignoring his adultery, having sex on demand, or not accessing contraceptives since limiting numbers of children limits masculine virility. Women can leave their marriage, especially if there are no children or her bride wealth has not been received, and a man may throw out a lazy or adulterous wife. For some abused women, the only recourse seems to be a form of 'negative agency' (Wardlow 2006) manifested as self-destructive violence in the form of suicide (see Counts 1993; Scaletta 1986). The most dangerous 'ghost' for a man is that of his wife who committed suicide or died in childbirth as a consequence of spousal abuse.

Case 4. (1985) After a visit to another village, I returned to find a close kinswoman with a black eye, swollen face and bandaged forehead. I was told that her husband was annoyed with her constant 'nagging' at him to do some work to repair garden fences and to fix the roof of the house before the monsoon rains came. He silenced her complaints by hitting her several times with his fists. This was very unusual behaviour for these two people; retrospectively, this was the beginning of the end of their thirty plus years of marriage.

Case 5. (2003) A young mother who had been severely beaten the night before came to me for first-aid and told me her story. While she was napping in the afternoon, her husband took her string bag (TP: bilum) to bring back pumpkins from their garden. When he returned, she flew into a rage at him for taking her only and thus her best string bag. He responded to her angry tirade by giving her a black eye as well as several cuts on her back where he hit her with his machete. Most of the cuts were minor, but one was long and quite deep and should have been stitched had medical care other than my first-aid been available.

Case 6. (2003) Next day, while changing the bandages for the woman in case 5 above, another injured woman arrived. Her husband had beaten her the evening before with an axe handle. Her scalp was swollen in two spots around a deep gash and she was bruised and swollen on her back and on her forearm, which she had raised to fend off the blows. She told me what led up to the event. She was returning from the garden with a fully loaded string bag hanging down her back from the strap on her forehead, a basket with a load of tubers balanced on her head, and a child too young to walk on her hip. She slipped and fell, spilling everything; inadvertently, the child was hit by spilled sweet potatoes. Shaken and tired, she arrived home and began to prepare the evening meal. The baby cried and woke its father who ordered his wife to quiet the child. Her husband demanded a fork, and the wife told him to get it himself. But their firstborn daughter handed her father the fork. The mother then hit the girl, knocking her down, for indulging the father. The husband then attacked his wife for not 
bringing him his fork, for not quieting the infant who was crying due to being hurt by falling sweet potatoes (i.e. it was the wife's fault), and for hitting the daughter.

In these examples women were beaten because they were verbally aggressive, nagged or disobeyed their husbands. I had witnessed the wifely scolding in case 4 many times before, but they had never resorted to violence. After this event, the wife simply stopped being a wife. She stopped speaking to him. She served his food last, often flinging it in the direction where he was sitting or setting it where he had to get up and fetch it. Eventually she stopped feeding him at all, so the husband turned to his daughters-in-law and to me for food and when his wife refused to share a house with him, he moved into his son's house. From the moment of their fight and over several years, I watched this marriage of thirty years or more with six adult children fall apart. She did not attend his funeral some years later and in 2009, when we looked at pictures where he was included, she showed no emotion at all or simply walked away.

Everyone remarked on the young woman in case 5 who had had her second child within eleven months of her first, necessitating the weaning of the firstborn. With two infants on her hands, and not much sympathy from other women, she did not go to her gardens very often. The village in general was fed up with her firstborn who flew into temper tantrums, was in constant distress, and cried day and night. The mother was blamed for the child's behaviour because she was too lustful and 'worried' (i.e. concerned) about sex; thus, she breached the postpartum taboo on sexual intercourse while breast feeding. She became pregnant too soon thus necessitating early weaning of the firstborn, whose behaviour was later attributed to the affect of breast milk contaminated by sperm. This is an interesting illustration of how married women are responsible for policing their own and their husband's sexual desires during postpartum, since men are considered incapable of controlling their own sexual urges. Both the blame for the child's behaviour and the fault for the woman's problematic second pregnancy were acknowledged to be her inability to control her sexuality, and no one said that he shouldn't have had sex with her. While people said the husband should not have beaten her so badly, they did say that she 'deserved it' for being so unreasonable about a string bag. After all, pumpkins are not dirty like sweet potatoes.

The woman in example 6 is tired, carrying a very heavy load, bruised from a fall, harassed by a crying child, stressed by her late return as she rushed to collect water and prepare a meal in the dark. Her husband had apparently been in the village all day. In this example, the husband struck out at his wife when she challenged his lazy behaviour with an aggressive raised voice, nagging, and refusal to comply. Husbands are deemed justified in beating their wives for such angry outbursts of disrespect. As I tried to patch her up, she pointed out to 
me (rather gleefully, actually) that because of her badly injured arm and head, she was unable to carry food and water or prepare meals. But her husband was not inconvenienced as their ten-year-old daughter, who had witnessed the entire altercation, took on her mother's daily chores-laundry, minding the baby, collecting water and food, cooking - and obeying her father. In this way, gender roles and rules, gendered inequalities and inequities are transmitted to the next generation of women as the enculturation process engenders both girl and boy children.

Case 7. (2005) During my usual census taking, I met a girl of seventeen who was the unmarried mother of a six-month-old daughter. She was living with her mother and I discovered the girl's pregnancy was a consequence of rape. The girl had been living with her 'uncle' (a patrilineal kinsman) in another village so she would be closer to her school. The uncle pressured her for sex and forced her into an affair with him. When she became pregnant and informed her family, her furious elder brother set upon the 'uncle' and beat him very badly and then he beat his pregnant sister so severely, her mother said, that she was unable to walk for days. The 'uncle' was summoned to local court where on arrival he was again set upon and given a severe beating. He managed to get away; the court case was dropped because the local magistrate felt the man had been punished enough. The uncle moved to the mainland to avoid any further attacks. On my next visit to the village, the girl and her child had been sent to a relative in town where she would be nanny and housekeeper while her 'aunt' worked.

Case 8. (2009) I followed up on a story I had heard about on my previous trip. A youth with a reputation for causing trouble locally forced his patrilateral cross-cousin (a taboo, incestuous relationship) into having sexual intercourse; he raped her. He threatened that if she told anyone he would 'cut' her. Initially formed under duress and threat the relationship developed to the point where the girl began to enjoy her sexual relationship with her cousin. A kinswoman had seen the youth sneaking into and out of the girl's sleeping area and reported to the girl's father who decided to keep quiet to avoid gossip and trouble from kinspeople. They tried to keep the two apart; but, despite this, the youth continued to stalk the girl who under duress again gave in to his demands. She became pregnant and when she told her family, they decided on a bushmedicine abortion. But nothing stays quiet in a village; indeed, the girl herself told other girls the 'secret' of her affair and abortion. Her father's agnates heard and turned up to beat the girl severely. During another altercation on this issue, a man lost a finger to an attacker's bush knife, and the girl was again beaten very badly. During my fieldwork in 2009, the youth was in and around the village and walked by my house each day en route to school; the girl and her child were living far away to protect her from her kin (and presumably from her cousin). She was not in school. 
In these two instances, young girls were forced into sexual intercourse by older men or by their peers with threats to their personal safety. While men may be beaten by the women's kinsmen when they find out, the ultimate blame and punishment is worn by the girls. Females are perceived to be lustful and unless women are controlled, their sexuality can wreak havoc and seduce men causing their downfall. Men on the other hand are perceived as always susceptible to the power of female sexuality, indeed they are powerless before it and, once excited are deemed unable to control their arousal which must be consummated even if that means rape, that is, ikado arala ('sexual intercourse') without the woman's consent. This was made clear to me in a discussion of the famed 'pocket trousers' which almost all village women now wear (usually under a sarong, see also Gibbs, Ch. 3). ${ }^{5}$ Because these knee-length pants have wide legs, if women sit improperly men might see up the trouser legs to the genital area; or, when toileting, women remove the trousers entirely, thus exposing themselves. Glimpses of forbidden bodies, a senior woman told me, inflames a man's desire to see more and to have sex. His desire will be ignited each time he sees the woman in passing and he might stalk her and rape her when he gets an opportunity. My female friend argued that these trousers were a main cause of rape and young women should not wear them. She bluntly noted that without question, men are unable (or are not expected) to control their sexual arousal which, once excited, must be consummated, if not at the moment, then whenever the opportunity arises.

The above examples all suggest a kind of impunity that surrounds men's recourse to physical or sexual violence against women that is inscribed in mythologies, taught from early life lessons, and lived routinely in women's experiences. In the Bullroarer myth, the slaughter of women for behaviour men perceived as emasculating continues to be 'not wrong' because a woman who transgresses masculine prerogative 'deserves' her punishment. This shows up time and again in situations where women who express their thoughts, nag, disobey or otherwise offend their husbands or fathers are 'deserving' of masculine abuses because their behaviour drove him to it; thus, it is his duty to 'teach her a lesson.' Similarly, when women are sexually attacked, it is her sexuality that caused her to be raped, not the rapist's inability to regulate his own sexuality (see also Zorn Ch. 5 and Hukula Ch. 6).

\section{Violence in the name of our father}

Missionisation is a form of structural violence built on an ethnocentric perception of the inferiority of the missionised peoples' culture, society and

5 Apparently, the number of pockets on the pocket pants is not the issue with this garment at all. 
indigenous spirituality. Missionisation has had dramatic effects on women (Jolly 2000: 307), and Catholic or Protestant, the Christian message and Biblical teaching 'legitimized forms of domestic violence, the corporal discipline of husbands over wives and of parents over children, performed not in the name of indigenous hierarchy but Christian love' (2000: 308). Catholicism has reinforced Bariai gender constructs and their indigenous patriarchal ideology of masculine authority and privilege, women's inferior status in society and the household, and women's primary role as wife, child bearer and labourer. While women do not endure exclusion from participating in Christian beliefs and rituals, they are constantly being asked to sacrifice themselves in the name of the Father, in the name of marital and familial peace, and for the sake of their souls (see Hermkens 2007, 2008 and Ch. 4). Bariai men (and some women) have taken Catholic teachings against birth control as further evidence that women interfere with the reproductive process at their peril; not only will their husbands beat them, but now they will also spend eternity in Hell. Catholicism has reinforced Bariai patriarchal authority and obedience, the concept of female lust and original sin, and masculine pro-natalism.

During 1982, when the local health nurse came to discuss family planning with the women, the local catechist, whom I will refer to as Geri, warned all women, in a public moot, that they need not attend the nurse's discussion because contraception was against the laws of the Pope. Only three women and I attended the meeting. Geri later stopped by to chat with me about the church's position on family planning. He explained to me, that the church forbade birth control, which he interpreted as murder, on the premise that Papa God gave women the ability to create life and thus interference with this process through contraception and/or abortion is murder. He lectured me that the purpose of marriage is to beget children and to increase the population (i.e. be fertile and multiply).

This seemed to coincide with other discussions I was having with Bariai men who expressed concern about their lack of 'development,' which they saw as a consequence of not receiving government attention and assistance for development projects because their population (about 1000 at the time) was too small to warrant government support. A burgeoning population, they believed, would hasten government assistance with economic development. Family planning was thus a way to 'keep the people down' by encouraging them to break the law of God (and be punished for their sins) and by diminishing the population (and be punished by a lack of development projects and access to modernity). According to Geri, the church position on birth control ${ }^{6}$ might be reconsidered only if (1) a woman is sick and unable to have children without

6 This has also carried over into the non-use of condoms as protection against STIs or HIV (see McPherson 2008b). 
risking her own life; (2) a couple already has more than ten children and are worried about being able to provide for them; or (3) one or the other parent does not provide well for the family. In these instances, the couple must first present their case to the lay catechist (Geri) who might/might not agree that they have a case to take to the parish priest. If the request for family planning is approved by the parish priest, wife and husband must both attend the clinic to receive contraceptives. Since the 'husband is head of family', a woman cannot access birth control without his consent and thus without his presence there. A woman who secretly practised birth control was disobeying her husband, committing a sin against the church, and impeding government development projects for everyone. She was also accused of 'shutting herself down' so she could indulge her sexuality with any number of men and not suffer the telltale consequences of unwanted pregnancy. A woman who might secretly access birth control, or even if she has not will - after a reasonable time of non-conception-be beaten for her efforts (see above and Scaletta 1986).

During fieldwork over the past ten years, married women have told me that if they refuse sex or practise birth control, their husbands will abandon them or take a second wife. If a husband leaves for another woman, it is perceived to be the wife's fault for somehow driving him away. To be left a single parent with even one child, let alone five or six, condemns the woman to a life of exceptionally hard work, dependence on others, and an overriding sense of shame and failure. Thus, some women fret with jealousy when their husbands are away in the bush or visiting another village or town, fearing that they may find another woman/wife. Men for their part complain about their wives' jealousies, and some tend to stay close to home and their wife in order to avoid quarrels about their fidelity. This combination of masculine sexual privilege, a wife's 'duty' to have sex with her husband on demand, sexual jealousy, threats of violence and abandonment and no contraception make for frequent marital sex, many babies, and may account for the burgeoning practice (condemned by the church) of polygyny among young men in the village.

\section{Sexual jealousies: The perils of polygyny and many babies}

Case 9. (2009) A young couple with a three-month-old child were constantly fighting because of their sexual jealousies. The woman left her husband (went home to her mother) and the husband left the village for several weeks. He returned with a new wife from a neighbouring culture/linguistic group who did not know that he already had a wife and child. His first wife attacked and thrashed the second wife, kicking and screaming and accusing her of seducing her husband away. The second wife had been living with the man as her husband for weeks and would be ashamed to return home having been 'used' 
in this way. So she stayed. There were two more altercations between the two women and quarrels between the woman and her husband. The first wife left to stay with her mother at the far end of the village. But her father exerted his authority and berated her for her unruly behaviour, told her to go back to her husband and live with him and his new wife. If she didn't he, that is her father, would beat her into wifely submission. The first wife fled to another village, frightened of her father and his threat to beat her, but was too stubborn to accept a polygamous marriage. She stayed away for some weeks and when she came back, she tried to live with her husband and his second wife in the same house and the same bed.

The dual pressures on women to provide sex on demand from husbands (or lovers) and admonishments from the church that sex is only for the purpose of having babies have increased the number of births per woman. Up to about 1985, women observed a postpartum taboo on sexual intercourse for the period the child is breast fed (up to three years or more, see example 5 above). Bariai conceptualise the female body to include a 'tube' that connects breasts with womb. Thus semen entering her vagina would travel along the 'tube' to contaminate her breast milk and the nursing child would become ill and possibly die from respiratory problems. My censuses and genealogies, now going back ten generations, show that to 1985, this postpartum taboo contributed to an average birth spacing per woman of one child every four years.

Sometime in the 1990s, Catholicism really took hold and, encouraged by their husbands, women stopped observing the postpartum taboo on the basis that western medicines, such as antibiotics and rehydration kits, could cure any childhood illness (especially respiratory problems, diarrhoea) caused by semen in mother's milk. My censuses in 2003, 2005 and 2009 showed an astonishing increase in births and decrease in birth spacing as women averaged two births in three years, or even, as in the case cited above, two children in eleven months. This did not go unnoticed by senior women who were grandmothers who remarked to me that in their mother's day, nobody had such large families of children; rather they had two or three children per family. ${ }^{7}$ These older women pointed to how young women's daily work had increased to breaking point. As women are now averaging larger families of six to ten children and often have both toddlers and an infant to care for at the same time, they need to create more and larger gardens to cultivate more food. They also needed to go to the gardens more frequently to harvest because they couldn't carry much more than one day's food. They also used more water and thus had to haul

7 It should be noted that there is a difference between the number of pregnancies a woman has and the number of living children she has. From what I can tell from colonial reports, the infant mortality rate in Bariai was not very high at all, nor was the maternal mortality rate. Senior women in the 1980s explained that when women had two or three living children, they accessed bush medicine for contraceptive purposes. 
more water from the stream on a daily basis, and they did far more laundry. Women also worked harder to make larger gardens to have produce to sell as a source of cash income to pay for processed foods (rice, sugar, tin meat and fish, treats), clothes, and school fees for their children. They also spent their nights fishing for bêche de mer (sea cucumber) to sell to the buyers who came regularly. This extra work has an effect on women's health, but also on girl children who are increasingly depended upon by their mothers for carrying water, cooking, laundering, gardening and caring for younger children. Consequently, girls are regularly pulled out of school to do this work.

Such contemporary fecundity results from a network of intersecting factors. Both men and women allowed that the postpartum taboo isn't necessary anymore due to the availability of western medicines which would cure childhood illnesses believed to be caused by semen-contaminated breast milk. The Catholic Church encourages wives to defer to and obey their husbands as patriarchs and authoritative heads of family and to fulfil their wifely duties to provide sex for reproduction, though not recreational purposes (see Hermkens 2007, 2008 and Ch. 4) and punishes any form of birth control as a sin. Transgressors are spiritually threatened to an afterlife in Hell and husbands physically punish real or imagined efforts by their wives to practise birth control. Thus, women are having too many babies too close together. Two infants in three years means that the nursing infant is weaned too soon, and the mother is not having sufficient recovery time between pregnancies. Frequent pregnancies, inadequate birth spacing, and increased manual labour, have a detrimental effect on women's overall health. If sex is by spousal demand and only for reproduction, fathering many children validates the constant indulgence of men's sexual demands, their virile masculine identity, and reinforces their adamant refusal to practise 'family planning'. Both forms of patriarchal authority-husbands in the family and priests in the church - are aligned in meting out punishment to women who want to use birth control methods to space or curtail their pregnancies.

Married women also pointed out to me it is very difficult to deny a husband sexual access since any lack of interest in marital sex a wife exhibits is taken to mean she is having sex with someone else. She is likely to be beaten for adultery and/or raped by her husband to teach her a lesson about male authority and wifely duty and obedience. Men use a kind of emotional blackmail wrapped in threats of abandonment and immoral behaviour on her part and wives acquiesce to avoid being beaten, to forestall false accusations about their fidelity, and to keep their husbands. The ban on birth control also prevents women from using or requesting the use of condoms as protection against HIV infection (see McPherson 2008b).

Another key factor in this mix is that the last men's ceremonial house (B: lum) built in 1985 has long since been razed with no replacement built (or, as of 2009, 
even planned). With the demise of the men's ceremonial house (B: lum ), which housed spirit beings, sacra and Bariai cosmology in the late 1980s, the Catholic Church has assumed a central role in defining the Bariai world view, their ethos and daily life. For the past twenty years men's lives are no longer homosocial, framed by the men's house as the icon of gendered exclusivity and enforcing the sexual division of space and place. As of 2000, residential sexual segregation is no longer practised; men do not retire to the men's house to share masculine company, to teach and learn, to plan ceremonies, eat, and sleep away from the seduction and dangers of the female sex. Indeed, the family has become the Christian nuclear family consisting of husband, wife, and dependent children living under the same roof. In contrast to the traditional matrifocal household, when males lived separately in the ceremonial men's house, married men now live in the 'woman's house' (B: luma), with their wife/wives and children. The husbands, under the aegis of church teaching that he is the patriarchal head of household and indigenous concepts of masculine power and privilege, has assumed the role of overseer of the household and of women's domestic labour. The domestic domain is no longer a female domain; husbands have taken control of the household, bossing and finding fault with women's work in the home, village, and gardens, an intrusion that often ends up in arguments and physical violence. Two examples will help illustrate some of these factors.

\section{Contested domestic power}

Case 10. (2009) Everyone liked to have their photograph taken, so villagers and I decided that I would systematically go from house to house and photograph each nuclear family - father, mother, children. As I got to the last house in one hamlet, the husband called out to me to meet them underneath the house, which I assumed they wanted as their background in the snapshot. When I arrived, I saw the wife from behind, hunched over tightly holding her infant. Another woman looked on, visibly upset. I enquired if the baby was unwell, but the husband loudly proclaimed that he had just beaten his wife severely with a branch. Couldn't I see the gash on her head, her swollen face and arm, the blood on the sitting platform and on the ground? He said there was no point taking their photo today as the younger children were frightened and had run away into the bush and not come back. Furious and anxious for my woman friend, I demanded to know why he had beaten his wife. His answer: she had disobeyed him. He had specifically told her not to sell her bêche-de-mer to buyer A because he didn't pay as well as another buyer, B. Buyer A had come in that morning and she had sold to him against her husband's express orders to wait for buyer B. Surely that's no reason to beat her, I said. No, he laughed, he beat 
her to teach her a lesson, to teach her to do as she was told and not to go against his instruction. He was after all 'head of the family' and 'boss' of his wife and children.

We had a bit of a discussion about his behaviour specifically and men's behaviour generally in beating their wives before I left to take the next household's picture. When I arrived at this next house, everyone there immediately told me that the man I had just left had been beating his wife and how they could hear the poor woman shrieking and crying in pain. It was awful what he was doing, they said, he should never use a stick. But, they didn't intercede, because this was a private matter between husband and wife. Indeed, the whole village buzzed with this event, yet no one (except a very few women) condemned or censured the husband as his wife had disobeyed his authority and women know they will attract a beating for this; and, besides, it was a 'private', family affair. This is a big departure from past understandings when kinspeople would interfere in a situation of spousal abuse to ensure it didn't get out of control. There was no such presumption of a household's privacy. Often the woman's clan brothers would turn up to chastise their brother-in-law about how he was abusing their sister, and that perhaps he should rethink his behaviour.

The scenario of the failed family photograph took place a few days before my departure from the village. When the wife in example 10 didn't turn up to my going away feast three days later, I enquired after her to a group of women. One woman replied that she was still swollen and bruised, but it had been three days and she should be over it by now. In general, women's pragmatism in the face of abuse that they, as I know from experience, also suffer, reinforces my contention that violence is engendered and embodied within a framework of 'cultural violence' that both men and women come to accept as a way of life. My final example occurred the day before I left the village to return home.

Case 11. (2009) I was sitting plaiting pandanus textiles with some women, when a senior woman approached and called me aside. She handed me something carefully wrapped in a plastic rice bag. It turned out to be a photograph, so blotched with mildew that only a small face at the bottom of the photo was visible. This was her deceased daughter and she wanted me to send her a new copy of the photo. Her daughter had married into a neighbouring village and her husband had killed her during an argument. He was hitting her and she fell down whereupon he kicked her very hard, many times in the ribs. A rib broke and punctured her heart. This ruined photograph was her only remembrance of her daughter. I had not taken this particular photograph. However, I offered to bring her only precious copy home with me to get her daughter's image photo-shopped. My local camera store did a great job and my friend now has a plasticised photo of her dead daughter. 
Why had they been arguing? Who knows, newly married people argue a great deal as they settle into married life, usually about sex, fidelity, and jealousy. Was the husband arrested and charged with his wife's murder? No, the husband was made to pay a large compensation in money (K10,000 or approximately $\$ 4200$ CAD), plus a few pigs and traditional shell valuables. The deceased woman's family didn't want to put themselves in danger (of sorcery) by demanding police, homicide charges, and courts. It is doubtful that her death was even registered officially. So, a young woman's life is valued at about $\$ 4200$ together with a few pigs and shell valuables. All that remained was a tattered photograph lovingly protected in a plastic rice bag by her mother.

\section{Some final thoughts}

I began this look at spousal abuse and men's violence against women by agreeing with the Seville Statement on Violence which proclaims that masculine violence is not an essential feature of human biology or human evolution. Instead, I suggested that violence in general and masculine violence against women in particular is culturally embedded in concepts of gendered relations and therefore, violence is a learned trait. Employing Galtung's concept of 'cultural violence' or the ways in which violence is culturally legitimised and justified, I considered examples of Bariai myths as primal charters for masculine violence against women and male social, sexual and sacred privilege. I then observed how violence informs child rearing and domestic life. The enculturation process, in this instance the transmission of a culturally legitimised violence, is obvious in how Bariai children, both boys and girls, are taught from infancy to be aggressive and to hit out at others. The several examples of specific incidents of violence I have described and analysed illustrate how 'cultural violence' finds expression in the lives of women and men. Men have 'power over' women in terms of patriarchal authority underwritten both by indigenous masculine world views and by the Catholic Church. All these cases illustrate a masculine 'power over' wives and daughters. Women are enculturated as much as men, and most (not all) accept cultural concepts of their gender and sexuality, their subordinate position in the social structure, and the physical abuse they all suffer because they are female, woman, wife and daughter. Men feel they have a right, indeed, an obligation to beat their wives given that women are culturally defined as weak-minded, weak-willed, and need to be taught lessons and controlled. The notion that 'lessons' are best learned when beaten onto the body is not totally expunged from the culture and history of corporal punishment in child-rearing practices, patriarchal violence, and spousal abuse in Euro American societies. In the past, spousal abuse was seen as a private behaviour within the family, behind closed doors. Excessive violence was culturally determined by a 'rule of thumb' 
whereby a wife couldn't be hit with anything bigger than a circumference of a man's thumb. There was a notion that children ought not to be spared the rod, and wives needed to be beaten into submission.

The examples presented here show how gender relations cannot be understood through essentialist sociobiological or evolutionary explanations such as 'manthe-hunter' scenarios of masculine sexual aggression and violence. Rather, a cultural ethos of engendered violence justifies and legitimates beliefs and behaviours, becomes part of a cultural narrative that creates a consensus shared by women and men alike. Gender relations are thus relations grounded in masculine 'power over' the feminine. With very few exceptions, all Bariai men and women hold that physical violence against women is permissible in certain circumstances. A wife will be beaten (and she expects to be) when she fails to fulfil her obligations to produce food (productive labour); fails to produce children (reproductive labour); fails to care for her husband's pigs (produce wealth); or when she refuses or is reluctant to have sexual intercourse with her husband. Further, all females were refused access to the secret-sacred aspects of the men's house culture where spirit beings and important ceremonials were carried out under threat of institutionalised rape and murder. Most women believe in (although some question) their gendered inadequacies as much as men do. It is this enculturation process in all its complexity that makes gendered 'violence look, even feel right — or at least, not wrong' (Galtung 1990: 291).

\section{References}

Banks, Cyndi, 2000. Contextualising sexual violence: rape and carnal knowledge in Papua New Guinea. In Reflections on Violence in Melanesia, ed. Sinclair Dinnen and Allison Ley, 83-104. Sydney: Hawkins Press and Asia Pacific Press.

Caputi, Jane, 1989. The sexual politics of murder. Gender \& Society 3(4): 437-56.

Chowning, Ann, 1985. Kove women and violence: the context of wife-beating in a West New Britain Society. In Domestic Violence in Papua New Guinea, ed. Susan Toft, 72-91. Monograph No. 3. Law Reform Commission, Port Moresby: Papua New Guinea.

Conkey, Margaret with Sarah Williams, 1991. Original narratives: the political economy of gender in archaeology. In Gender at the Crossroads of Knowledge: Feminist Anthropology in the Postmodern Era, ed. Micaela di Leonardo, 10239. Berkeley CA: University of California Press. 
Counts, Dorothy A., Judith K. Brown and Jacquelyn C. Campbell, 1992. Sanctions and Sanctuary: Cultural Perspectives on the Beating of Wives. Boulder, CO: Westview Press.

Counts, Dorothy A., 1992. 'All men do it': wife-beating in Kaliai, Papua New Guinea. In Sanctions and Sanctuary:Cultural Perspectives on the Beating of Wives, ed. Dorothy Ayers Counts, Judith K. Brown and Jacquelyn C. Campbell, 63-76. Boulder, CO: Westview Press.

1993. The fist, the stick and the bottle of bleach: wife bashing and female suicide in a Papua New Guinea Society. In Contemporary Pacific Societies: Studies in Development and Change, ed. Victoria S. Lockwood, Tom G. Harding and Ben J. Wallace, 249-59. New Jersey: Prentice Hall.

Dinnen, Sinclair and Allison Ley, eds, 2000. Reflections on Violence in Melanesia. Sydney: Hawkins Press and Asia Pacific Press.

Eves, Richard, 2006. Exploring the Role of Men and Masculinities in Papua New Guinea in the 21st Century: How to address violence in ways that generate empowerment for both men and women. Report for Caritas Australia. Online: http://www.baha.com.pg/downloads/Masculinity \%20and \%20 Violence\%20in\%20PNG.pdf. Accessed 28 November 2010.

Farmer, Paul, 2004. An anthropology of structural violence. Current Anthropology 45(3): 305-25.

2005. Pathologies of Power: Health, Human Rights and the New War on the Poor. Berkeley, CA: University of California Press.

Galtung, Johan, 1990. Cultural violence. Journal of Peace Research 27(3): 291305.

Gewertz, Deborah, 1988. Myths of Matriarchy Reconsidered. Sydney: Oceania Monographs.

Gewertz, Deborah B. and Frederick K. Errington, 1991. Twisted Histories, Altered Contexts: Representing the Chambri in a World System. Cambridge: Cambridge University Press.

Hammar, Lawrence, 1996. Bad canoes and bafalo: the political economy of sex on Daru Island, Western Province, Papua New Guinea. Genders 23: 212-43.

Hays, Terence and Patricia H. Hays, 1982. Opposition and complementarity of the sexes in Ndumba initiation. In Rituals of Manhood: Male Initiation in Papua New Guinea, ed. Gilbert H. Herdt, 201-38. Berkeley: University of California Press. 
Heise, Lori L., 1997. Violence, sexuality, and women's lives. In The Gender/ Sexuality Reader: Culture, History, Political Economy, ed. Roger N. Lancaster and Micaela di Leonardo, 411-32. New York: Routledge.

Herdt, Gilbert H., ed., 1982. Rituals of Manhood: Male Initiation in Papua New Guinea. Berkeley: University of California Press.

Hermkens, Anna-Karina, 2007. The power of Mary in Papua New Guinea. Anthropology Today 23(2): 4-8.

------- 2008. Josephine's journey: gender-based violence and Marian devotion in urban Papua New Guinea. Oceania 78(2): 151-67.

Hussey, Mark, ed., 2003. Masculinities: Interdisciplinary Readings. Upper Saddle River, NJ: Prentice Hall.

Jolly, Margaret, 2000. Epilogue: further reflections on violence in Melanesia. In Reflections on Violence in Melanesia, ed. Sinclair Dinnen and Alison Ley, 305-24. Sydney: Hawkins Press and Asia Pacific Press.

Keesing, Roger, 1982. Introduction. In Rituals of Manhood: Male Initiation in Papua New Guinea, ed. Gilbert H. Herdt, 1-43. Berkeley: University of California Press.

Krohn-Hansen, Christian, 1994. The anthropology of violent interaction. Journal of Anthropological Research 50: 367-81.

McCaughey, Martha, 2008. The Caveman Mystique: Pop-Darwinism and the Debates over Sex, Violence and Science. New York: Routledge.

McPherson, Naomi M., 1994. The legacy of Moro the Snake-Man in Bariai. In Children of Kilibob: Creation, Cosmos and Culture in Northwest New Guinea, ed. Alice Pomponio, David R. Counts and Thomas G. Hardy. Special issue. Pacific Studies 17(4): 153-81.

2008a. Galiki the firstborn: mythic female and feminine ideal in Bariai, West New Britain, Papua New Guinea. In Sexual Snakes, Winged Maidens and Sky Gods: Myth in the Pacific, An Essay in Cultural Transparency, ed. Serge Dunis, 181-201. Nouméa and Pape'ete: La Rocher-à-la-Voile and Éditions Haere Po Tahiti.

2008b. SikAIDS: deconstructing the awareness campaign in rural West New Britain, Papua New Guinea. In Making Sense of AIDS: Culture Sexuality, and Power in Melanesia, ed. Leslie Butt and Richard Eves, 328-54. Honolulu: University of Hawai'i Press. 
Poole, John Fitz Porter, 1982. The ritual forging of identity: aspects of person and self in Bimin-Kuskusmin male initiation. In Rituals of Manhood: Male Initiation in Papua New Guinea, ed. Gilbert H. Herdt, 99-154. Berkeley: University of California Press.

Riches, David, 1986. The phenomenon of violence. In The Anthropology of Violence, ed. David Riches, 1-27. Oxford, Basil Blackwell.

Scaletta, Naomi (McPherson), 1986. Childbirth: a case history from West New Britain, Papua New Guinea. Oceania 57: 33-52.

Silverman, Eric Kline, 2001. Masculinity, Motherhood, and Mockery: Psychoanalyzing Culture and the Iatmul Naven Rite in New Guinea. Ann Arbor: University of Michigan Press.

Stewart, Pamela and Andrew Strathern, 2002. Violence: Theory and Ethnography. London: Continuum.

Tracy, Karen K. and Charles B. Crawford, 1992. Wife abuse: does it have an evolutionary origin? In Sanctions and Sanctuary: Cultural Perspectives on the Beating of Wives, ed. Dorothy A. Counts, Judith K. Brown and Jacquelyn C. Campbell, 19-32. Boulder, CO: Westview Press.

Tuzin, Donald, 1997. The Cassowary's Revenge: The Life and Death of Masculinity in a New Guinea Society. Chicago: University of Chicago Press.

Wardlow, Holly, 2006. Wayward Women: Sexuality and Agency in a New Guinea Society. Berkeley: University of California Press.

Zimmer-Tamakoshi, Laura, 2001. 'Wild pigs and dog men:' rape and domestic violence as women's issues in Papua New Guinea. In Gender in Cross Cultural Perspective, ed. Caroline B. Brettell and Carolyn F. Sargent, 565-80. Upper Saddle River, NJ: Prentice Hall, 3rd ed. 